\title{
Compositional Optimization of High-Performance Ferritic (HiperFer) Steels-Effect of Niobium and Tungsten Content
}

\author{
Xiuru Fan ${ }^{1,2}$, Bernd Kuhn ${ }^{1, *(\mathbb{C})}$, Jana Pöpperlová ${ }^{3} \mathbb{C}^{\text {, }}$, Wolfgang Bleck ${ }^{3}$ and Ulrich Krupp ${ }^{3}$ \\ 1 Institute of Energy and Climate Research (IEK), Microstructure and Properties of Materials (IEK-2), \\ Forschungszentrum Jülich GmbH, 52425 Jülich, Germany; x.fan@fz-juelich.de \\ 2 Central Iron \& Steel Research Institute (CISRI) Group, Material Digital R\&D Centre, Beijing 100081, China \\ 3 Steel Institute, RWTH Aachen University (IEHK), Intzestr. 1, 52072 Aachen, Germany; \\ Jana.Poepperlova@iehk.rwth-aachen.de (J.P.); bleck@iehk.rwth-aachen.de (W.B.); \\ Krupp@iehk.rwth-aachen.de (U.K.) \\ * Correspondence: b.kuhn@fz-juelich.de; Tel.: +49-2461-61-4132
}

Received: 31 August 2020; Accepted: 28 September 2020; Published: 29 September 2020

check for updates

\begin{abstract}
The combined addition of $\mathrm{Nb}$ and $\mathrm{W}$ provides increased solid solution and precipitation strengthening by $(\mathrm{Fe}, \mathrm{Cr}, \mathrm{Si})_{2}(\mathrm{Nb}, \mathrm{W})$-Laves phase particles of ferritic, $17 \mathrm{wt} . \% \mathrm{Cr}$ stainless highperformance ferritic (HiperFer) steel. Based on alloy modifications and the obtained hardness, tensile, and creep testing results; a new high alloying variant is proposed as a candidate steel for future structural application up to approximately $680{ }^{\circ} \mathrm{C}$ in power engineering and the process industry.
\end{abstract}

Keywords: HiperFer; Laves phase; precipitate strengthening; solid solution strengthening; creep

\section{Introduction}

High-chromium, ferritic stainless steels are widely known for their excellent high-temperature oxidation resistance, but are typically considered to be non-hardenable, and thus not applicable for structural application at an elevated temperature. Previous research demonstrated that viable creep properties can be obtained in ferritic steel based on precipitation of a variety of intermetallic phase precipitates [1-4]. A proprietary development at Forschungszentrum Juelich $\mathrm{GmbH}$, Germany, features a ferritic stainless steel strengthened by a combination of solid solution strengthening and precipitation of $(\mathrm{Fe}, \mathrm{Cr}, \mathrm{Si})_{2}(\mathrm{Nb}, \mathrm{W})$-Laves phase particles [5-8]. Optimization of these high-performance ferritic (HiperFer) steels so far cumulated in an alloy, which can combat the strongest low-cost, heat-resisting structural steels [9] typically applied in power engineering and the process industry up to approximately $680^{\circ} \mathrm{C}$. Alteration of the main Laves phase constituting elements $\mathrm{W}, \mathrm{Nb}$, and $\mathrm{Si}$ strongly influences the mechanical properties by modification of the solid solution and precipitation strengthening effects in such alloys. The relation of $\mathrm{W}$ and $\mathrm{Nb}$ contents directly affects short-term precipitation and long-term particle growth kinetics. This paper provides comprehensive information on the impact of combined $\mathrm{Nb}$ - and $\mathrm{W}$-addition on microstructure and some mechanical properties of HiperFer steel.

\section{Methods and Materials}

\subsection{Alloy Design and Production}

Based on the HiperFer 17Cr2 (2.4W0.6Nb) prototype alloy [9-12], the chemical compositions of the trial alloys were systematically varied in thermodynamic equilibrium calculations (utilizing the commercial software package Thermocalc ${ }^{\circledR}$, database: TCFE7), including an increase in niobium to $1 \mathrm{wt.} \%$ and a variation in tungsten content from $2.4 \mathrm{wt} . \%$ up to $4 \mathrm{wt} . \%$ (Table 1). High-purity lab melts were then 
manufactured by vacuum induction melting of high-purity raw materials, casting, soaking at $1250{ }^{\circ} \mathrm{C}$ for $2 \mathrm{~h}$, and forging ( 3 steps from $140 \times 140 \mathrm{~mm}^{2}$ to $92 \times 92 \mathrm{~mm}^{2}$ in the temperature range from $1250{ }^{\circ} \mathrm{C}$ to $950{ }^{\circ} \mathrm{C}$, interstage annealing: $1250{ }^{\circ} \mathrm{C}, 20 \mathrm{~min}$.) at the Steel Institute of RWTH Aachen University. Prior to examination, all the materials were solution annealed (SA) at $1200{ }^{\circ} \mathrm{C}$ for $30 \mathrm{~min}$ and subsequently water quenched.

Table 1. Compositions of the base (17Cr2) and the high W/high $\mathrm{Nb}$ model alloys, wt.\%.

\begin{tabular}{ccccccc}
\hline Model Alloy & Cr & W & Nb & Si & Mn & Fe \\
\hline 17Cr2 $(2.4 \mathrm{~W} 0.6 \mathrm{Nb})$ & 17.10 & 2.41 & 0.63 & 0.25 & 0.18 & $\mathrm{R}$ \\
2.6W1Nb & 17.43 & 2.83 & 0.9 & 0.2 & 0.27 & $\mathrm{R}$ \\
3.1W1Nb & 17.37 & 3.27 & 1.0 & 0.2 & 0.23 & $\mathrm{R}$ \\
4W1Nb & 17.30 & 3.97 & 0.93 & 0.2 & 0.23 & $\mathrm{R}$ \\
\hline
\end{tabular}

\subsection{Microstructural Investigation}

Samples for microstructural investigation were cut from annealed specimens and cold mounted in epoxy resin for preparation. The mounted samples were ground and polished (applying diamond polish solution down to $1 \mu \mathrm{m}$ of roughness, followed by $\mathrm{Al}_{2} \mathrm{O}_{3}$ in dilute $\mathrm{KOH}$ solution, utilizing vibration polishing as the final step). The samples were then etched in ethanol/ $\mathrm{H}_{2} \mathrm{SO}_{4}$ solution for 3 to $5 \mathrm{~s}$. Images of a resolution of $6144 \times 4608$ pixels were taken utilizing a Zeiss Merlin high-resolution field emission scanning electron microscope (HR-FESEM). The images were analyzed quantitatively (utilizing the software package analySIS pro) applying the method reported by Lopez et al. [13].

\subsection{Mechanical Testing}

Vickers hardness testing, applying $10 \mathrm{~N}$ of testing force (i.e., $\mathrm{HV}_{1}$ ) in a Buehler Micromet ${ }^{\circledR} 1$ hardness tester, was performed to evaluate the effect of alloying on solid solution hardening, precipitation kinetics, and particle hardening. Ambient temperature tensile experiments were performed at flat, miniature size specimens (gauge dimensions: $10 \times 2 \times 1 \mathrm{~mm}^{3}$ ). The tensile tests were carried out applying a strain rate of $10^{-3} \mathrm{~s}^{-1}$, utilizing an Instron 1362 testing machine. Compression creep experiments at cylindrical miniature (d: $3 \mathrm{~mm}$, h: $3.5 \mathrm{~mm}$ ) specimens were carried out at $650{ }^{\circ} \mathrm{C}$ in an Instron 8862 testing machine (Instron, Darmstadt, Germany). A type $S$ thermocouple was attached to the specimen to control the testing temperature to an accuracy of $+/-1{ }^{\circ} \mathrm{C}$. The decrease in effective testing stress by specimen strain was neglected, but limited by restriction of the maximum strain to less than $2 \%$. All the mechanical testing specimens were cut by electrical discharge machining.

\section{Results and Discussion}

\subsection{Thermodynamic Modelling of Alloy Compositions}

Figure 1 displays simplified, calculated phase diagrams of the alloy compositions given in Table 1. According to the calculations, the increase in $\mathrm{Nb}$-content improved the stability temperature range of the so-called high-temperature Laves $\left(\mathrm{HT}_{\mathrm{L}}\right.$, cf. Figure 1$)$ phase from less than $1000{ }^{\circ} \mathrm{C}$ to about $1100{ }^{\circ} \mathrm{C}$ in comparison to the $17 \mathrm{Cr} 2$ prototype steel. The improvement in the stability (from less than $650{ }^{\circ} \mathrm{C}$ to about $740{ }^{\circ} \mathrm{C}$ ) range and the volume fraction (less than $0.5 \%$ to more than $1 \%$ ) of the so-called low-temperature $\left(\mathrm{LT}_{\mathrm{L}}\right.$, cf. Figure 1) Laves phase indicated that the addition of $\mathrm{Nb}$ preferentially benefited the nucleation of the $\mathrm{LT}_{\mathrm{L}}$ phase. $\mathrm{W}$ had a positive effect on the phase fractions of both the types of Laves phase too [14].

The calculations indicate the $\mathrm{LT}_{\mathrm{L}}$ phase as an equilibrium phase; but in light of the results outlined in [15-18], it rather has to be considered a metastable, non-equilibrium phase. In this respect, the description of the Laves phase in the applied database does not seem accurate enough for correct calculations in the present alloying system. 


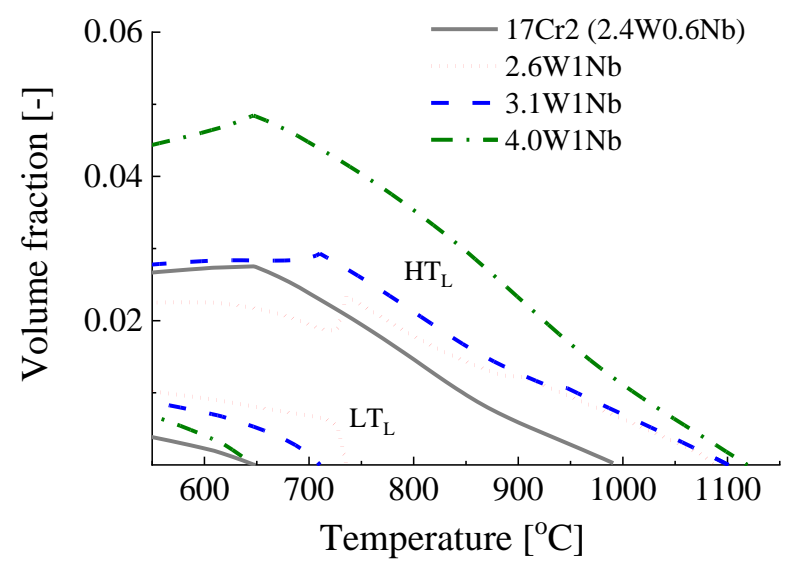

Figure 1. Phase volume fraction of the high $\mathrm{W} /$ high $\mathrm{Nb}$ trial alloys in comparison to the HiperFer 17Cr2 [9-12] prototype alloy (calculated utilizing the commercial software package Thermocalc ${ }^{\circledR}$, database: TCFE7).

In contrast to the calculations, the combined addition of $\mathrm{W}$ and $\mathrm{Nb}$ in the investigated ranges did not trigger the undesirable $\sigma$-phase precipitation at temperatures equal or higher than $600{ }^{\circ} \mathrm{C}$ [8] in the presented steels.

\subsection{Precipitation Behaviour}

Typical microstructures of the steels after annealing at $650{ }^{\circ} \mathrm{C}$ for $10 \mathrm{~h}$ are depicted in Figure 2. In comparison to the $17 \mathrm{Cr} 2$ alloy (Figure 2a), the high alloy steels (Figure 2b-d) presented higher densities of finer Laves phase particles.

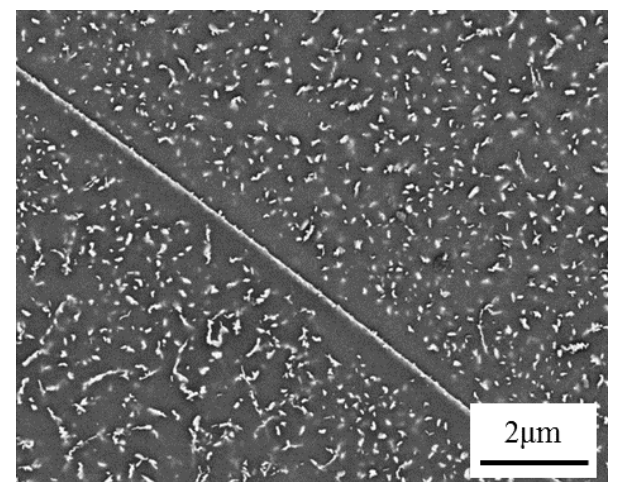

(a)

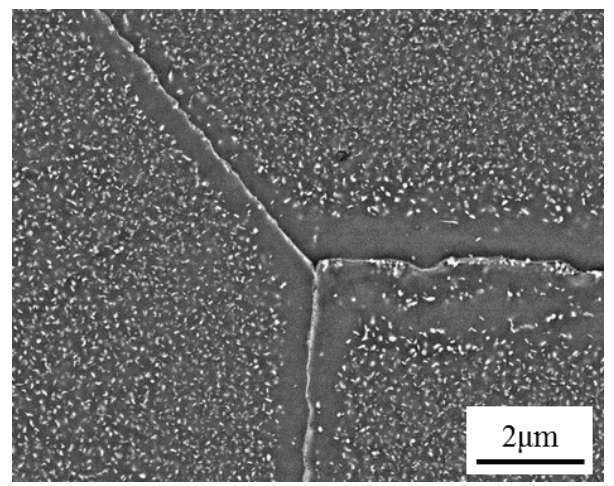

(c)

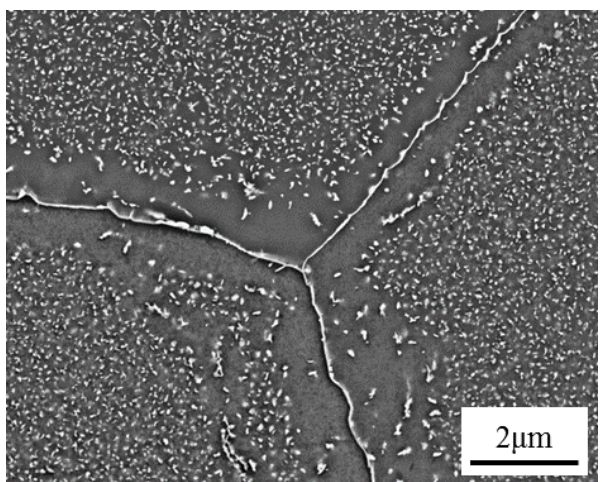

(b)

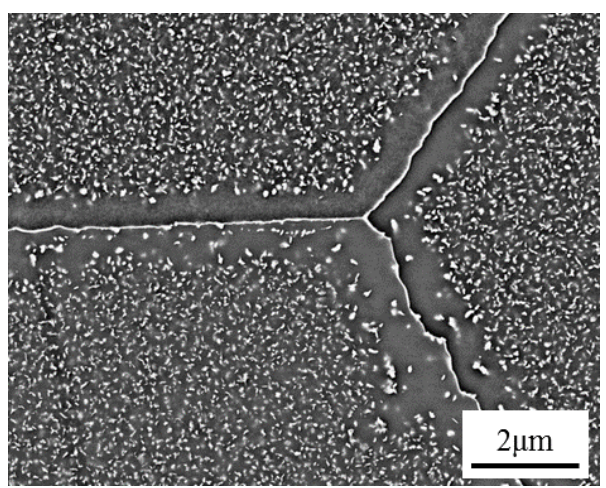

(d)

Figure 2. Microstructures of the precipitation-treated steels: (a) $17 \mathrm{Cr} 2(2.4 \mathrm{~W} 0.6 \mathrm{Nb})$ base alloy; (b) $2.6 \mathrm{~W} 1 \mathrm{Nb}$; (c) $3.1 \mathrm{~W} 1 \mathrm{Nb}$; and (d) $4 \mathrm{~W} 1 \mathrm{Nb}\left(\mathrm{SA}+650^{\circ} \mathrm{C} / 10 \mathrm{~h}\right)$. 
Quantitative image analysis was applied to characterize the intragranular precipitation behavior of the high $\mathrm{W} /$ high $\mathrm{Nb}$ alloys during aging at $650{ }^{\circ} \mathrm{C}$. Figure 3 a displays the particle volume fraction evolution of the trial and the base steels. The corresponding average ECD (equivalent circle diameter) data is displayed in Figure $3 b$.

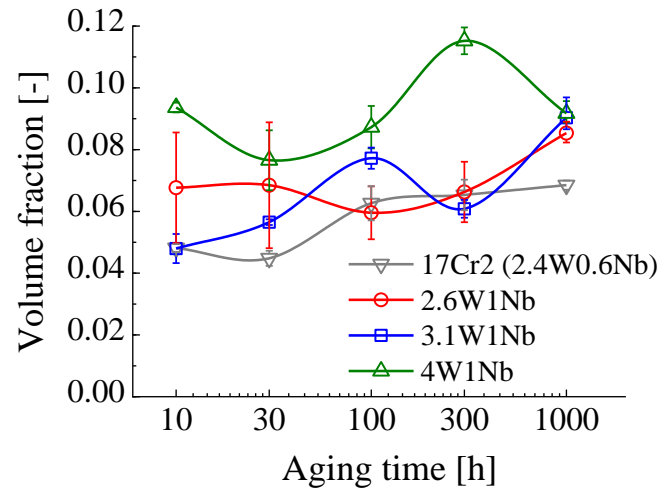

(a)

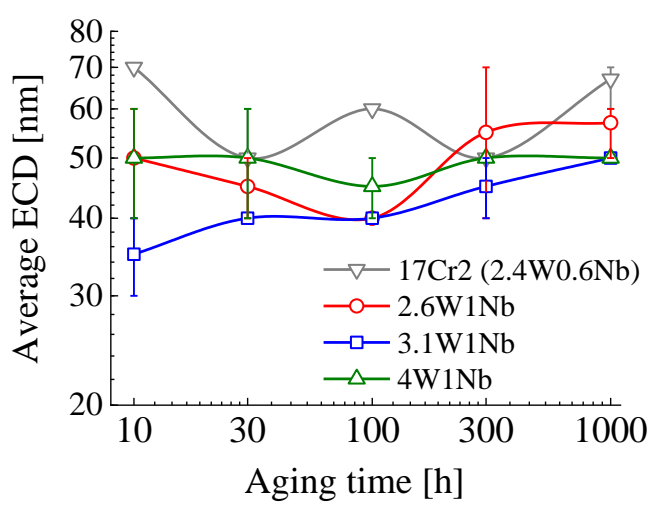

(b)

Figure 3. Evolution analysis during annealing at $650^{\circ} \mathrm{C}$ : (a) volume fraction evolution; (b) average equivalent circle diameter (ECD) evolution.

Within the range of scatter, but still significant, all the alloys presented complex, "wavy" area fractions and ECD evolution. Precipitation of the $\mathrm{LT}_{\mathrm{L}}$ and $\mathrm{HT}_{\mathrm{L}}$ phases took place at differing kinetics [15-18], which directly influenced the results of quantitative image analysis. Undoubtedly, all the trial alloys provided higher precipitate fractions after $1000 \mathrm{~h}$ of aging (Figure 3a). The measured fractions were almost a factor of two higher than predicted by thermodynamic calculation (Figure 1), which is most probably caused by the fact that, after just $1000 \mathrm{~h}$ at the annealing temperature of $650{ }^{\circ} \mathrm{C}$, equilibrium conditions were not yet reached. With increasing $\mathrm{W}$-content, the mean particle diameter decreases by about 20\% (Figure 3b).

The impact of $\mathrm{Nb}$-addition can be directly observed from comparison of the $17 \mathrm{Cr} 2$ base $(2.4 \mathrm{~W} 0.6 \mathrm{Nb})$ to the $2.6 \mathrm{~W} 1 \mathrm{Nb}$ trial alloy. $\mathrm{Nb}$ obviously increased the volume fraction of precipitates mainly during a short time of annealing (Figure 3a) and additionally refined the particles (Figure 3b). Because $\mathrm{Nb}$ is the main element in $\mathrm{LT}_{\mathrm{L}}$ phase core nucleation [15-18], the concentration of $\mathrm{Nb}$ directly influenced nucleation kinetics and amount of the initially formed Laves $\mathrm{LT}_{\mathrm{L}}$ phase precipitates. At 1 wt.\% of $\mathrm{Nb}$ concentration, the extra addition of $\mathrm{W}$ further increased particle volume fraction. The precipitate size evolution with time indicates that the addition of $\mathrm{W}$ stabilized size. Considering the $\mathrm{W}$-rich shell structure of the early stage $\mathrm{LT}_{\mathrm{L}}$ phase particles [15-18], the segregation of the slowly diffusing tungsten to the particle/matrix phase boundary is the rate determining process for the size growth of particles in the long term. Higher concentration of $\mathrm{W}$ in the alloy matrix thus leads to a higher driving force for the segregation of $\mathrm{W}$ to the particle/matrix interface, and by this decreases the growth of the $\mathrm{LT}_{\mathrm{L}}$ phase precipitates (i.e., the transformation of $\mathrm{LT}_{\mathrm{L}}$ to $\mathrm{HT}_{\mathrm{L}}$ phase).

\subsection{Mechanical Properties}

\subsubsection{Hardness Evolution}

The evolution of ambient temperature hardness with annealing time at $650{ }^{\circ} \mathrm{C}$ can be utilized as a preliminary indicator for the effectiveness of the implemented changes in alloy composition. The hardness of all alloys increased rapidly in short-term aging (Figure 4a), reached a plateau value, and then remained quasi stable. With the addition of $\mathrm{Nb}$, a pronounced increase in hardness can be observed, e.g., approximatily $10 \mathrm{HV}_{1}$ by comparing the $17 \mathrm{Cr} 2(2.4 \mathrm{~W} 0.6 \mathrm{Nb})$ and the $2.6 \mathrm{~W} 1 \mathrm{Nb}$ alloy. The addition of $\mathrm{Nb}$ boosted the precipitation of strengthening Laves phase particles and shortened the time to the plateau level to approximately $1 \mathrm{~h}$ at $650^{\circ} \mathrm{C}$. W-addition obviously delays precipitation. 


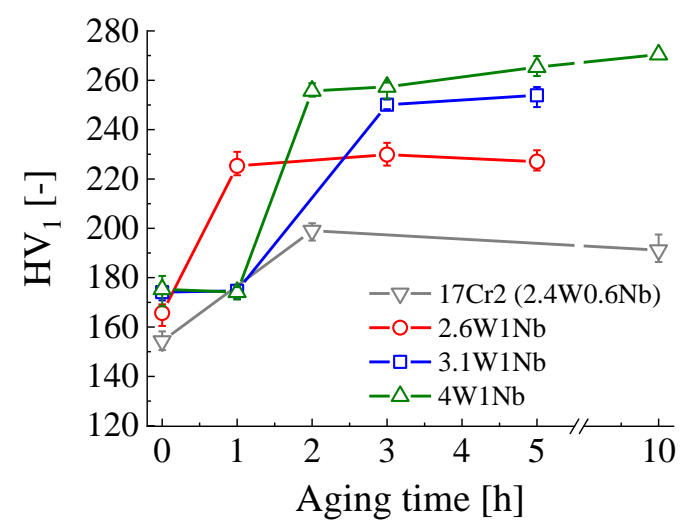

(a)

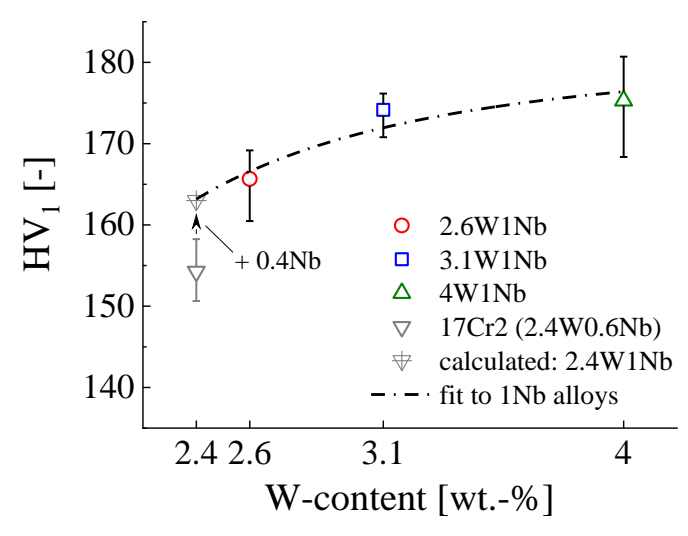

(b)

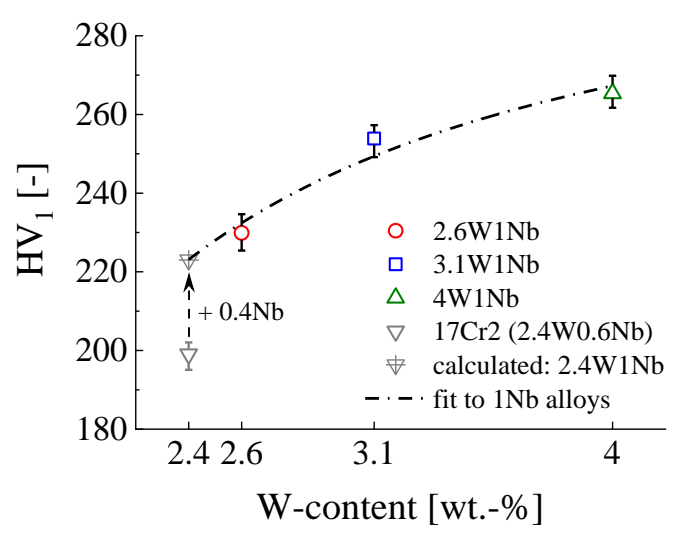

(c)

Figure 4. (a) Evolution (average of 5 measurements each) of the base and trial alloys in annealing at $650{ }^{\circ} \mathrm{C}$. (b) Impact of $\mathrm{W}$ - and $\mathrm{Nb}$-contents on hardness in the solution annealed state (virtual $2.4 \mathrm{~W} 1 \mathrm{Nb}$ alloy calculated by eliminating the effect of $\mathrm{W}$ by backward extrapolation of the $1 \mathrm{Nb}$ alloys, equation: $\mathrm{HV}_{1}=\mathrm{a} \times\left(1-\mathrm{c}_{\mathrm{W}}^{-\mathrm{b}}\right) ; \mathrm{c}_{\mathrm{W}}$ : W-content in wt.\%, a: 180.73, b: 2.68); and after $5 \mathrm{~h}$ of aging (c) ( equation: $\mathrm{HV}_{1}=\mathrm{a} \times\left(1-\mathrm{c}_{\mathrm{W}}^{-\mathrm{b}}\right) ; \mathrm{c}_{\mathrm{W}}$ : W-content in wt.\%, a: 305.47, b: 1.45).

In the solution annealed state (i.e., $0 \mathrm{~h}$ in Figure $4 \mathrm{a}, \mathrm{b}$ ), the additions of $\mathrm{Nb}$ and $\mathrm{W}$ both benefited solid solution strengthening. An attempt to calculate the effect of sole $\mathrm{Nb}$-addition to the base steel $(17 \mathrm{Cr} 2(2.4 \mathrm{~W} 0.6 \mathrm{Nb})+0.4 \mathrm{wt} . \%=$ fictious $2.4 \mathrm{~W} 1 \mathrm{Nb})$ by mathematical backward extrapolation (cf. Figure $4 \mathrm{~b}$ ) of the effect of tungsten content to $2.4 \mathrm{wt} . \%$ yielded a $6 \%$ rise in hardness up to $163 \mathrm{HV}_{1}$ (from $154 \mathrm{HV}_{1}$ in case of the $2.4 \mathrm{~W} 0.6 \mathrm{Nb}$ base steel) for the virtual $2.4 \mathrm{~W} 1 \mathrm{Nb}$ alloy.

The addition of $0.2 \mathrm{wt} . \% \mathrm{~W}$ resulted in a further increase to $166 \mathrm{HV}_{1}$ in the case of the $2.6 \mathrm{~W} 1 \mathrm{Nb}$ material. Rising W-content resulted in values of $174 \mathrm{HV}_{1}(3.1 \mathrm{~W} 1 \mathrm{Nb})$ and $175 \mathrm{HV}_{1}(4 \mathrm{~W} 1 \mathrm{Nb})$ equaling another gain by $7 \%$. The encountered substitutional effect of $\mathrm{W}$ on ferrite hardness correlates well with literature data [19]. The influence of $\mathrm{Nb}$ - and $\mathrm{W}$-contents on hardness in the short-term aged state (i.e., precpitatation annealed at $650^{\circ} \mathrm{C}$ for $5 \mathrm{~h}$ ) is displayed in Figure $4 \mathrm{c}$. The plateau hardness values of the alloys are sensitive to both the $\mathrm{Nb}$ and $\mathrm{W}$ concentrations. After $5 \mathrm{~h}$ of aging, the hardness increase of the virtual $2.4 \mathrm{~W} 1 \mathrm{Nb}$ alloy calculated to $223 \mathrm{HV}_{1}$. In comparison to $210 \mathrm{HV}_{1}$ measured at the $2.4 \mathrm{~W} 0.6 \mathrm{Nb}$ alloy, this gave a rise by $6 \%$ with the increase of $0.4 \mathrm{wt} . \%$ in $\mathrm{Nb}$-content. Progressively adding $\mathrm{W}$ provided a gain to $230 \mathrm{HV}_{1}(2.6 \mathrm{~W} 1 \mathrm{Nb}), 254 \mathrm{HV}_{1}(3.1 \mathrm{~W} 1 \mathrm{Nb})$, and $265 \mathrm{HV}_{1}(4 \mathrm{~W} 1 \mathrm{Nb})$; equaling another overall incremet of $19 \%$. 


\subsubsection{Tensile Strength in the Solution Treated State (i.e., Solid Solution Hardening Effect)}

Figure 5 illustrates the change in ambient temperature tensile strength values with increasing $\mathrm{W}$ and $\mathrm{Nb}$ additions of the solution annealed materials, i.e., the solid solution strengthening effects of these alloying elements. Starting from the $17 \mathrm{Cr} 2\left(2.4 \mathrm{~W} 0.6 \mathrm{Nb}, \mathrm{YS}_{0.2} / \mathrm{UTS}: 225 / 301 \mathrm{MPa}\right)$ base alloy, combined addition of $\mathrm{Nb}$ and $\mathrm{W}$ caused a gain in yield strength/UTS to $269 / 321 \mathrm{MPa}$ in case of the $2.6 \mathrm{~W} 1 \mathrm{Nb}$ trial steel. Further increase in W-content resulted in yield strength/UTS values of 280/336 MPa for the $3.1 \mathrm{~W} 1 \mathrm{Nb}$ and $289 / 361 \mathrm{MPa}$ for the $4 \mathrm{~W} 1 \mathrm{Nb}$ alloy. The impact of $\mathrm{W}$ on ultimate tensile strength was obviously more pronounced than on yield stength, while $\mathrm{Nb}$ demonstrated greater effect on yield.

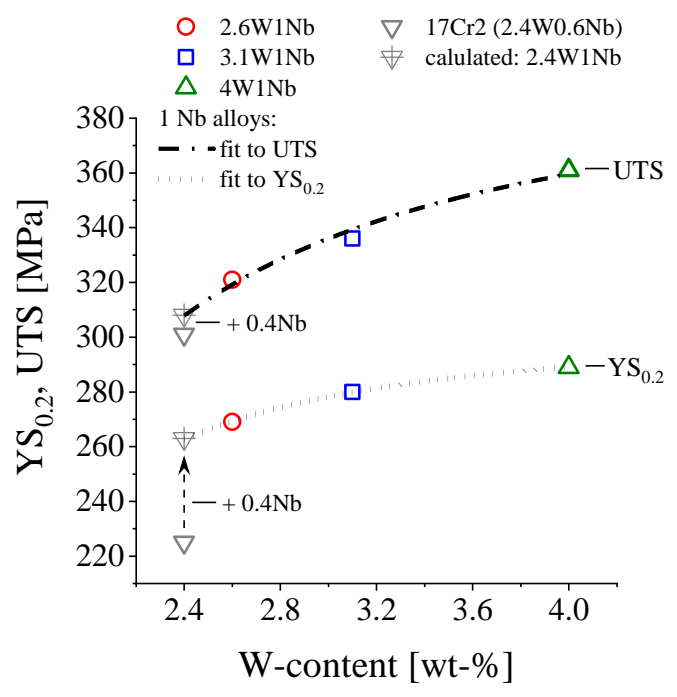

Figure 5. Solution effects of $\mathrm{W}$ and $\mathrm{Nb}$ on ambient temperature tensile strength values with (virtual $2.4 \mathrm{~W} 1 \mathrm{Nb}$ alloy, equation: $\mathrm{YS}_{0.2}=\mathrm{a} \times\left(1-\mathrm{c}_{\mathrm{W}}{ }^{-\mathrm{b}}\right)$; $\mathrm{c}_{\mathrm{W}}$ : W-content in wt.\%, a: 300.05, b: 2.38; UTS $=\mathrm{a} \times\left(1-\mathrm{c}_{\mathrm{W}}{ }^{-\mathrm{b}}\right)$; $\mathrm{c}_{W}: \mathrm{W}$-content in wt.\%, a: 396.53, b: 1.71).

The calculation for the effect of sole Nb-addition to the base steel $(17 \mathrm{Cr} 2(2.4 \mathrm{~W} 0.6 \mathrm{Nb})+0.4 \mathrm{wt} . \%$ = fictious $2.4 \mathrm{~W} 1 \mathrm{Nb}$ ) by mathematical linear backward extrapolation of the $\mathrm{W}$-tungsten content to $2.4 \mathrm{wt} . \%$ for the virtual $2.4 \mathrm{~W} 1 \mathrm{Nb}$ alloy gave a yield strength of $262 \mathrm{MPa}$ and a UTS value of $308 \mathrm{MPa}$. The strength values in the solution-annealed condition may appear to disqualify HiperFer steels for high-temperature application. However, these alloys are developed to enable short quality heat treatment at the envisaged operating temperature or even age hardening by rapid precipitation kinetics. The tensile strength values achieveable in this way were significantly higher (i.e., after $1-5 \mathrm{~h}$ of annealing @ $650{ }^{\circ} \mathrm{C}: \mathrm{YS}_{0.2} / \mathrm{UTS}: 400 / 660 \mathrm{MPa}$ in case of the $2.4 \mathrm{~W} 0.6 \mathrm{Nb}$ and $530 / 820 \mathrm{MPa}$ in case of the $4 \mathrm{~W} 1 \mathrm{Nb}$ alloy [9]).

\subsubsection{Compression Creep}

The obtained steady state creep rate vs. stress relations of the precipitation treated $\left(650^{\circ} \mathrm{C} / 5 \mathrm{~h}\right)$ alloys are displayed in Figure 6. From the experimental data the stress exponents $n$ (cf. Figure 6a) are calculated by applying the Norton-Bailey's law [20-22]:

$$
\varepsilon=A \sigma^{n},
$$

with $A$ being a constant, $\sigma$ representing the creep stress and $n$ representing the exponent of stress. 


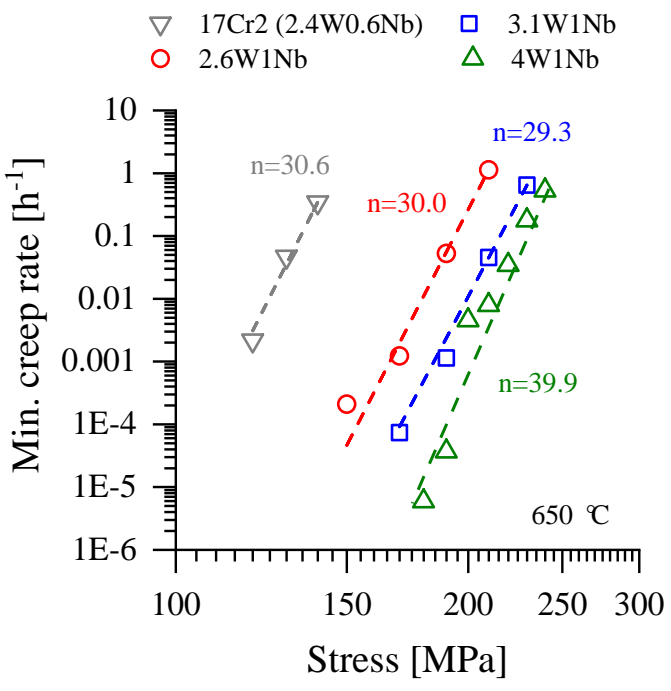

(a)

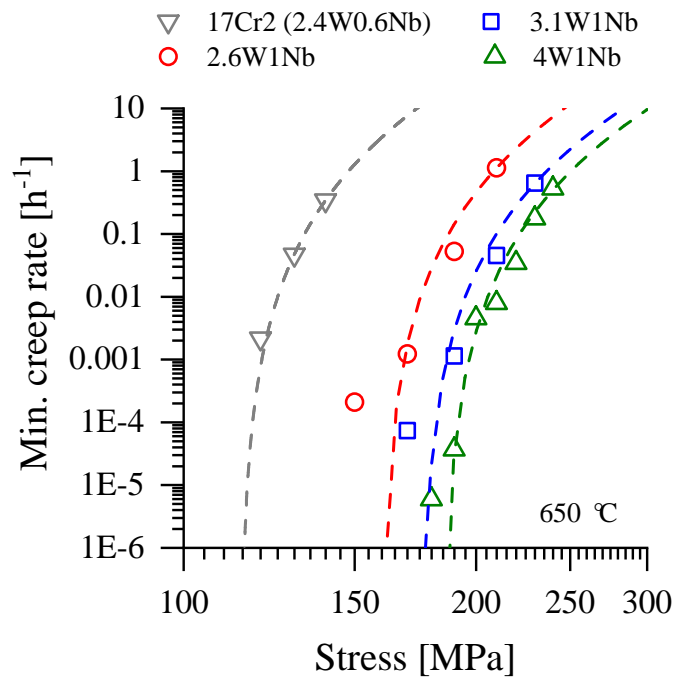

(b)

Figure 6. Data of the trial steels and the 17Cr2 base alloy. Fitted by (a) the Norton-Bailey relation [20,21] and (b) a modified Mukherjee-Bird-Dorn equation [23,24]. All specimens were precipitation treated prior to testing for $5 \mathrm{~h}$ at $650{ }^{\circ} \mathrm{C}$ (testing temperature: $650{ }^{\circ} \mathrm{C}$ ).

Increasing the concentrations of $\mathrm{Nb} / \mathrm{W}$ from $0.6 / 2.4 \mathrm{wt} . \%$ (in the $17 \mathrm{CrCr}$ base steel) to $1 / 2.6 \mathrm{wt} . \%$ (2.6W1Nb trial steel) yielded no change in stress exponent, but resulted in a drop in creep rate of about 4.5 orders of magnitude. Further raising the W-content to 3.1 and $4 \mathrm{wt} . \%$ resulted in a further decrease by another 3.5 orders of magnitude. While the stress exponent merely did not change with increasing $\mathrm{W}$-content from 2.6 to $3.1 \mathrm{wt} . \%$, instead it rose to 39.9 in case of the $4 \mathrm{~W} 1 \mathrm{Nb}$ steel.

High stress exponents $(n>10)$ indicated interaction between precipitates and matrix dislocations, and thus, are typical for precipitation strengthened materials. Applying a modified Mukherjee-Bird-Dorn [23] equation

$$
\mathrm{d} \varepsilon / \mathrm{d} t=A\left(\left(\sigma-\sigma_{t h}\right) / \mu\right)^{n \prime} \exp \left(-Q / k_{B} T\right),
$$

(with $A$ being a constant, $\mu$ representing the shear modulus of the alloy matrix, $\sigma$ the applied creep stress, $\sigma_{t h}$ the threshold stress, $n^{\prime}$ the matrix stress exponent $\left(n^{\prime}=4[23,24]\right), Q$ the creep activation energy, and $k_{B}$ the Boltzmann constant) to the creep data (Figure $6 \mathrm{~b}$ ) provides a threshold stress for dislocation creep. The threshold creep stresses were calculated for all the materials and are displayed in Figure 7 as a function of W-concentration.

The threshold improved from about $115 \mathrm{MPa}$ in case of the $17 \mathrm{Cr} 2(2.4 \mathrm{~W} 0.6 \mathrm{Nb})$ base steel to appr. $160 \mathrm{MPa}$ for the $2.6 \mathrm{~W} 1 \mathrm{Nb}$ material and further to about $185 \mathrm{MPa}(4 \mathrm{~W} 1 \mathrm{Nb})$ by increasing the concentration of $\mathrm{W}$ in the $1 \mathrm{Nb}$ model alloys. The threshold values evaluated for the $17 \mathrm{Cr} 2$ $(2.4 \mathrm{~W} 0.6 \mathrm{Nb})$ prototype and the $4 \mathrm{~W} 1 \mathrm{Nb}$ alloys correlate well with the mechanism changes, obtained in uniaxial creep experiments, executed at full-scale specimens taken from rolled plate materials of matching chemical compositions [9]. The $17 \mathrm{Cr} 2(2.4 \mathrm{~W} 0.6 \mathrm{Nb})$ alloy surpasses the creep strength of grade 92 , while the $4 \mathrm{~W} 1 \mathrm{Nb}$ steel combats the strongest available advanced ferritic-martensitic steel MarBN [9]. Mathematical backward extrapolation of the W-tungsten content to $2.4 \mathrm{wt}$. $\%$ for the virtual $2.4 \mathrm{~W} 1 \mathrm{Nb}$ alloy calculates to a threshold of $158 \mathrm{MPa}$. In consequence, the effect of sole $\mathrm{Nb}$-addition $(+0.4 \mathrm{wt} . \%)$ to the $17 \mathrm{Cr} 2$ base steel would result in an increase in threshold of appr. $40 \mathrm{MPa}$. 


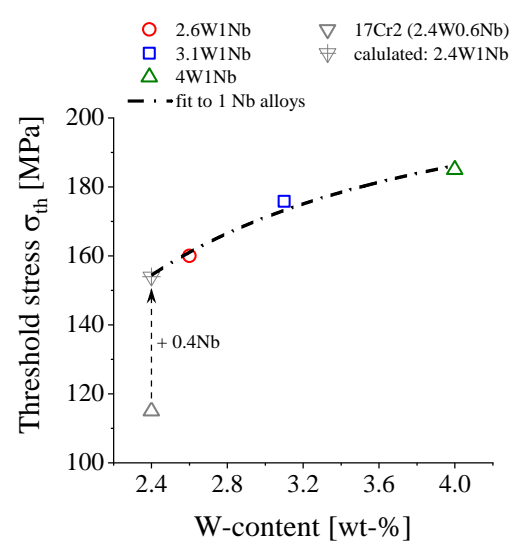

Figure 7. Impact of $\mathrm{W}$ and $\mathrm{Nb}$ on dislocation creep threshold stress (virtual 2.4W1Nb alloy, equation: $\sigma_{\mathrm{th}}=\mathrm{a} \times\left(1-\mathrm{c}_{\mathrm{W}}{ }^{-\mathrm{b}}\right) ; \mathrm{c}_{\mathrm{W}}: \mathrm{W}$-content in wt.\%, a: 215.27, b: 1.44).

\section{Conclusions}

The additions of $\mathrm{W}$ and $\mathrm{Nb}$ to $17 \mathrm{wt} . \%$ Cr HiperFer steel resulted in increased solid solution strengthening, increased volume fraction of Laves phase precipitates, and decreased mean Laves phase precipitate size. By this, hardness and tensile strength at ambient temperature as well as elevated temperature creep strength and fatigue resistance have been increased to values exceeding the strongest ferritic-martensitic steels [9] applied in power engineering and the process industry today. Empirical equations, describing the relations between $\mathrm{W}$-content and mechanical properties have been proposed, which are useful for further compositional optimization. The evaluated dislocation creep threshold values, derived from miniature compression creep data, correlate well with the ones measured at full-scale creep specimens from rolled plate material. This demonstrates the validity of the applied optimization approach and mechanical miniature testing methods for alloy performance improvement.

Author Contributions: Conceptualization, B.K., X.F., and J.P.; methodology, B.K., X.F., and J.P.; investigation, X.F. and J.P.; resources, B.K. and W.B.; data curation, X.F., B.K., and J.P.; writing-original draft preparation, X.F.; writing-review and editing, B.K., W.B., and J.P.; visualization, X.F. and B.K.; supervision, B.K. and W.B.; project administration, B.K., W.B., and U.K.; funding acquisition, B.K. and W.B. All authors have read and agreed to the published version of the manuscript.

Funding: Project funding by Deutsche Forschungsgemeinschaft (DFG) under grant number 631895 is greatly appreciated.

Acknowledgments: The authors also wish to thank the following staff members of Forschungszentrum Juelich GmbH: Egbert Wessel, Daniel Grüner (microstructural examination); Burkhard Werner and Harald Reiners (mechanical characterization).

Conflicts of Interest: The authors declare no conflict of interest. The funders had no role in the design of the study; in the collection, analyses, or interpretation of data; in the writing of the manuscript, or in the decision to publish the results.

\section{References}

1. Toda, Y.; Tohyama, H.; Kushima, H.; Kimura, K.; Abe, F. Influence of Chemical Composition and Heat Treatment Condition on Impact Toughness of 15Cr Ferritic Creep Resistant Steel. JSME A 2005, 48, 125-131.

2. Toda, Y.; Tohyama, H.; Kushima, H.; Kimura, K.; Abe, F. Improvement in creep strength of precipitation strengthened $15 \mathrm{Cr}$ ferritic steel by controlling carbon and nitrogen contents. JSME A 2005, 48, 35-40. [CrossRef]

3. Toda, Y.; Seki, K.; Kimura, K.; Abe, F. Effects of W and Co on Long-term Creep Strength of Precipitation Strengthened 15Cr Ferritic Heat Resistant Steels. ISIJ Int. 2003, 43, 112-118. [CrossRef]

4. Shibuya, M.; Toda, Y.; Sawada, K.; Kushima, H.; Kimura, K. Effect of nickel and cobalt addition on the precipitation-strength of 15Cr ferritic steels. Mater. Sci. Eng. A 2011, 528, 5387-5393. [CrossRef]

5. Froitzheim, J.; Meier, G.H.; Niewolak, L.; Ennis, P.J.; Hattendorf, H.; Singheiser, L.; Quadakkers, W.J. Development of high strength ferritic steel for interconnect application in SOFCs. J. Power Sour. 2008, 178, 163-173. 
6. Kuhn, B.; Asensio Jimenez, C.; Niewolak, L.; Hüttel, T.; Beck, T.; Hattendorf, H.; Singheiser, L.; Quadakkers, W.J. Effect of Laves phase strengthening on the mechanical properties of high Cr ferritic steels for solid oxide fuel cell interconnect application. Mater. Sci. Eng. A 2011, 528, 5888-5899. [CrossRef]

7. Hsiao, B.; Kuhn, Z.W.; Chen, D.; Singheiser, L.; Kuo, J.C.; Lin, D.Y. Characterization of Laves phase in Crofer $22 \mathrm{H}$ stainless steel. Micron 2015, 74, 59-64. [CrossRef] [PubMed]

8. Kuhn, B.; Talik, M.; Niewolak, L.; Zurek, J.; Hattendorf, H.; Ennis, P.J. Development of high chromium ferritic steels strengthened by intermetallic phases. Mater. Sci. Eng. A 2014, 594, 372-380. [CrossRef]

9. Kuhn, B.; Talik, M.; Fisher, L.; Fan, X.; Yamamoto, Y.; Lopez Barrilao, J. Science and Technology of High Performance Ferritic (HiperFer) Stainless Steels. Metals 2020, 10, 463.

10. Kuhn, B.; Talik, M.; Lopez Barrilao, J.; Singheiser, L. Microstructure Stability of Ferritic-Martensitic, Austenitic and Fully Ferritic Steels under Fluctuating Loading Conditions. In Proceedings of the 1st 123 HiMat Conference on Advanced High-Temperature Materials Technology for Sustainable and Reliable Power Engineering (123HiMAT-2015), Sapporo, Japan, 29 June-3 July 2015; pp. 94-97.

11. Kuhn, B.; Fischer, T.; Yamamoto, Y.; Lopez Barrilao, J.; Fan, X. Mechanical Properties and Application Potentials of High Performance Ferritic (HiperFer) Steels. In Proceedings of the 4th International ECCC Creep \& Fracture Conference, Duesseldorf, Germany, 10-14 September 2017.

12. Kuhn, B.; Lopez Barrilao, J.; Fischer, T. “Reactive” Microstructure: The Key to Cost Effective, Fatigue Resistant High Temperature Structural Materials. In Proceedings of the EPRI's 9th International Conference on Advances in Materials Technology for Fossil Power Plants and the 2nd International 123HiMAT Conference on High-Temperature Materials, Nagasaki, Japan, 21-25 October 2019; pp. 1-10.

13. Lopez Barrilao, J.; Kuhn, B.; Wessel, E. Identification, size classification and evolution of Laves phase precipitates in high chromium, fully ferritic steels. Micron 2017, 101, 221-231. [CrossRef] [PubMed]

14. Pöpperlová, J.; Fan, X.; Kuhn, B.; Bleck, W.; Krupp, U. Impact of tungsten on thermomechanically induced precipitation of laves phase in high performance ferritic (HiperFer) stainless steels. Appl. Sci. 2020, 10, 4472. [CrossRef]

15. Lopez Barrilao, J.; Kuhn, B. Microstructure Evolution of Laves Phase Strengthened Ferritic Steels for High Temperature Applications. Ph.D. Thesis, RWTH Aachen University-FZ, Jülich, Germany, 2016.

16. Lopez Barrilao, J.; Kuhn, B.; Wessel, E. Microstructure and intermetallic particle evolution in fully ferritic steels. In Proceedings of the 8th International Conference on Advances in Materials Technology for Fossil Power Plants, Albufeira, Portugal, 11-14 October 2016; pp. 1029-1037.

17. Lopez Barrilao, J.; Kuhn, B.; Wessel, E. Microstructure evolution and dislocation behaviour in high chromium, fully ferritic steels strengthened by intermetallic Laves phases. Micron 2018, 108, 11-18. [CrossRef] [PubMed]

18. Fan, X. Optimization of Laves Phase Strengthened High Performance Ferritic Stainless Steels. Ph.D. Thesis, RWTH Aachen University, Aachen, Germany, 5 May 2020. Available online: http://publications.rwth-aachen. de/record/792517/files/792517.pdf (accessed on 28 September 2020).

19. Thelning, K.E. Steels and Its Heat Treatment; Butterworth \& Co.: London, UK, 1984.

20. Norton, F.H. The Creep of Steels at High Temperatures; Mc Graw-HilI: New York, NY, USA, 1929.

21. Bailey, R.W. Creep of Steel under Simple and Compound Stresses, and the Use of High Initial Temperature in Steam Power Plants. In Proceedings of the Transactions of the World Power Conference, Tokyo, Japan, 29 October-7 November 1929; Volume 3, p. 1089.

22. May, D.L.; Gordon, A.P.; Segletes, D.S. The application of the norton-bailey law for creep prediction through power law regression. In Proceedings of the ASME Turbo Expo 2013: Turbine Technical Conference and Exposition, GT2013-96008, San Antonio, TX, USA, 3-7 June 2013.

23. Vo, N.Q.; Liebscher, C.H.; Rawlings, M.J.; Asta, M.; Dunand, D.C. Creep properties and microstructure of a precipitation-strengthened ferritic Fe-Al-Ni-Cr alloy. Acta Mater. 2014, 71, 89-99.

24. Yang, M.; Zhu, J.; Yang, T.; Luan, J.; Jiao, Z.; Fan, X.; Kuhn, B.; Xiong, X.; Wang, C.; Liu, C.T.; et al. A novel ferritic steel family hardened by intermetallic compound G-phase. Mater. Sci. Eng. A 2019, 745, 390-399. [CrossRef]

(C) 2020 by the authors. Licensee MDPI, Basel, Switzerland. This article is an open access article distributed under the terms and conditions of the Creative Commons Attribution (CC BY) license (http://creativecommons.org/licenses/by/4.0/). 